\title{
Peranan Kearifan Lokal Nelayan sebagai Upaya Penanggulangan Illegal Fishing
}

\section{The Role of Fishermen's Local Culture as an Effort to Overcome Illegal Fishing}

\author{
Amaliyah $^{1}$, Resky Amalia Syafiin'2 ${ }^{2}$ Monica $^{3}$ \\ 1. Fakultas Hukum Universitas Hasanuddin, Indonesia. E-mail: amaliyah.recht26@gmail.com \\ 2. Fakultas Hukum Universitas Hasanuddin, Indonesia. E-mail: sykiki62@gmail.com \\ 3. Fakultas Hukum Universitas Hasanuddin, Indonesia. E-mail: monicacharolina@gmail.com
}

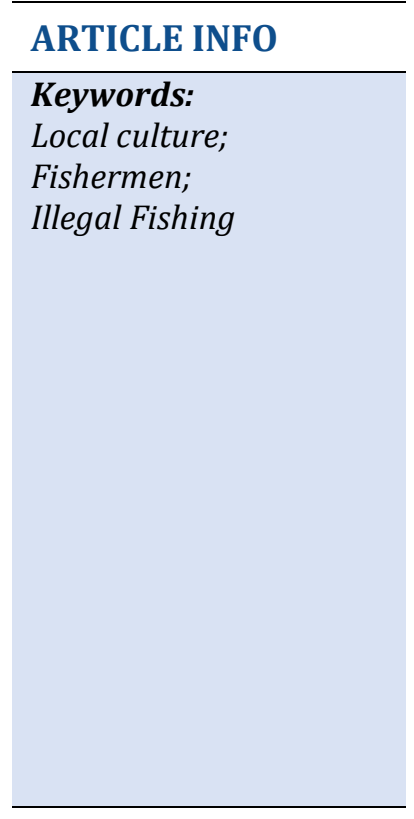

\section{INFO ARTIKEL}

Kata kunci:
Kearifan Lokal;
Nelayan;
Illegal Fishing

\begin{abstract}
This research is located in Barru Regency, South Sulawesi Province. This study aims to determine the form and intensity of illegal fishing activities that occur in Siddo Village in Barru District, examine the role of local fishermen's culture in efforts to tackle illegal fishing in Siddo Village in Barru District, and increase the government's role in following up on illegal fishing actions in Siddo Village in Barru District. This type of research is socio-legal research that is described in a descriptive qualitative manner. Data collection techniques used were observation, in-depth interviews (indepth interview), and literature study. Interviews were conducted with Barru District Court Judges, Barru District Fisheries Service Staff, Soppeng Riaja District office staff, Siddo Village office staff, and fishermen. Literature search is conducted to obtain secondary data such as supporting documents, research papers and other reference materials related to research. The research results obtained that in 2018 there was only one fishery case that was decided by the Barru District Court. Siddo village fishermen also still uphold the values of local culture in fishing activities. The fishermen use a trawl ring with a large 1-inch mesh net. Public awareness and not be tempted or interested in using modern technology still survive with whatever results are obtained to preserve the sea.
\end{abstract}

\footnotetext{
ABSTRAK

Penelitian ini berlokasi di Kabupaten Barru Provinsi Sulawesi Selatan. Penelitian ini bertujuan untuk mengetahui bentuk dan intensitas kegiatan illegal fishing yang terjadi di Desa Siddo Kabupaten Barru, menelaah peranan kearifan lokal nelayan dalam upaya penanggulangan illegal fishing di Desa Siddo Kabupaten Barru, dan meningkatkan peranan pemerintah dalam menindaklanjuti tindakan illegal fishing di Desa Siddo Kabupaten Barru. Jenis penelitian yang digunakan adalah penelitian sosio-legal yang dijabarkan secara deskriptif kualitatif. Teknik pengumpulan data yang digunakan adalah observasi, wawancara mendalam (indepth interview), dan studi kepustakaan. Wawancara dilakukan dengan Hakim Pengadilan Negeri Barru, Staf Dinas Perikanan Kabupaten Barru, staf kantor Kecamatan Soppeng Riaja, staf kantor Desa Siddo, dan nelayan. Penelusuran pustaka dilakukan untuk mendapatkan data sekunder seperti dokumen pendukung,
} 
makalah hasil penelitian serta bahan referensi lain yang berkaitan dengan penelitian. Hasil penelitian yang diperoleh bahwa pada tahun 2018 hanya ada satu kasus perikanan yang di putus oleh Pengadilan Negeri Barru. Nelayan desa Siddo juga masih memegang teguh nilai-nilai kearifan lokal dalam melakukan aktivitas penangkapan ikan. Para nelayan menggunakan pukat cincin dengan besar mata jaring 1 inci. Kesadaran masyarakat dan tidak tergiur atau tertarik menggunakan teknologi modern tetap bertahan dengan hasil apa pun yang diperoleh untuk menjaga kelestarian laut.

\section{Pendahuluan}

Secara geografis Indonesia membentang dari $6 \mathrm{LU}^{\circ}$ sampai $11 \mathrm{LS}^{\circ}$ dan 92。 sampai $142^{\circ}$ BT, terdiri dari pulau-pulau besar dan kecil. Tiga perempat wilayahnya adalah laut, dengan panjang garis pantai $99.093 \mathrm{~km}$, terpanjang kedua setelah Kanada. Melalui deklarasi Djuanda, 13 Desember 1957, Indonesia menyatakan kepada dunia bahwa laut Indonesia (laut sekitar, di antara, dan di dalam kepulauan Indonesia) menjadi satu kesatuan wilayah NKRI. Indonesia sebagai Negara kepulauan, telah diakui dunia internasional melalui konvensi hukum laut PBB ketiga, United Nation Convention on the Law of the Sea 1982 (UNCLOS 1982), kemudian diratifikasi oleh Indonesia dengan Undang-Undang No.17 Tahun 1985. Berdasarkan UNCLOS 1982, total wilayah laut Indonesia menjadi 5,9 juta $\mathrm{km}^{2}$, terdiri atas 3,2 juta $\mathrm{km}^{2}$ perairan teritorial dan 2,7 juta $\mathrm{km}^{2}$ perairan Zona Ekonomi Eksklusif, luas perairan ini belum termasuk landas kontinen (continental shelf). Hal ini menjadikan Indonesia sebagai Negara kepulauan terbesar di dunia the biggest Archipelago in the World) ${ }^{1}$

Kekayaan laut merupakan salah satu Sumber Daya Alam (SDA) dengan berbagai manfaat dan kegunaannya. Kekayaan sumber daya perikanan Indonesia meliputi, perikanan tangkap di perairan umum seluas 54 juta hektar dengan potensi produksi 0,9 juta ton/tahun. Tidak hanya itu, budidaya laut yang terdiri dari budidaya ikan (antara lain dengan kakap, kerapu, dan gobia), budidaya rumput laut dan budidaya air payau (tambak) memiliki potensi lahan pengembangan yang mencapai sekitar 913.000 ha. Total keseluruhan luas laut di Indonesia dan potensi sumber daya lautnya merupakan aset besar bagi bangsa ini.

Lembaga Ilmu Pengetahuan Indonesia (LIPI) menyebutkan perkiraan nilai potensi laut Indonesia berdasarkan potensi kekayaan alamnya sampai Maret 2019 senilai 1.772 Triliun. Jumlah tersebut terpetakan dari hasil perikanan sebanyak 312 Triliun, terumbu karang 45 Triliun, mangrove 21 Triliun, lamun 4 Triliun, 560 Triliun dari kekayaan pesisir, 400 Triliun dari bioteknologi, 20 Triliun dari wisata bahari, 210 Triliun dari minyak bumi, dan 200 Triliun dari transportasi laut. Dimana angka tersebut menyamai 93\% total pendapatan APBN Indonesia tahun 2018. Adapun untuk jenis ikan di wilayah perairan laut Indonesia terdapat beberapa jenis yang bernilai ekonomis tinggi antara lain tuna, cakalang, udang, tongkol, tenggiri, kakap, cumi-cumi, ikan-ikan karang (kerapu, baronang,

1 Ridwan Lasabuda, "Pembangunan Wilayah Pesisir dan Lautan dalam Perspektif Negara Kepulauan Republik Indonesia," Jurnal Ilmiah Platax 1, no. 2 (2013): 93. 
udang barong/lobster), ikan hias dan kekerangan termasuk rumput laut. ${ }^{2}$ Potensi ikan yang besar tersebutlah yang mendorong masyarakat untuk menggantungkan hidup dari hasil menangkap ikan yaitu dengan menjadi nelayan.

Berbagai metode diterapkan oleh nelayan guna memeroleh hasil tangkapan yang maksimal, mulai dari cara konvensional hingga modern. Bahkan tidak sedikit nelayan yang menerapkan metode menangkap ikan yang justru memberikan dampak buruk bagi ekosistem laut. Nelayan cenderung melakukan penangkapan ikan secara ilegal (illegal fishing), misalnya penangkapan secara destruktif guna memeroleh hasil yang melimpah. Penangkapan destruktif ialah jenis kegiatan pengambilan ikan dengan cara atau metode yang ilegal dan juga berdampak negatif pada populasi ikan dan habitat tempat tinggal ikan. Bom ikan, dinamit, racun ikan, pukat harimau adalah beberapa dari sekian banyak jenis metode penangkapan destruktif yang pada akhirnya berdampak pada terancamnya kelestarian sumber daya hayati laut. Pada umumnya alat-alat ataupun cara yang digunakan dalam melakukan penangkapan ikan yang tanpa mempertimbangkan ekosistem didominasi oleh alat tangkap modern.

Keberadaan alat-alat penangkapan yang modern menjadikan masyarakat dapat menangkap ikan lebih banyak lagi dengan intensitas waktu yang dibutuhkan relatif singkat dibandingkan menggunakan cara-cara tradisional. ${ }^{3}$ Meskipun demikian, teknologi modern tersebut tidak sepenuhnya dikembangkan oleh nelayan dalam perspektif positif karena beberapa penggunaan alat tangkap yang modern tidak mempertimbangkan dampak jangka panjang yang akan terjadi terkait kelestarian kekayaan bahari.

Praktik illegal fishing dalam hal ini penangkapan destruktif yang terjadi di perairan Indonesia menurut perhitungan Mantan Menteri kelautan dan perikanan Susi Pudjiastuti, akibat illegal fishing, kerugian negara per tahun bisa mencapai US\$ 20 miliar atau Rp 240 triliun. ${ }^{4}$ Hal ini sangat disayangkan, mengingat besarnya potensi laut seharusnya dapat memberikan keuntungan yang sebanding pula bagi negara. Oleh karena itu, sangat penting untuk mencegah dilakukannya penangkapan secara destruktif oleh nelayan, yaitu dengan menggunakan alat tangkap yang ramah lingkungan laut dan tidak dilarang dalam peraturan perundangan-undangan Indonesia.

Masyarakat nelayan yang patut dijadikan contoh dalam menerapkan metode penangkapan ikan adalah Masyarakat Desa Siddo yang terletak di Kabupaten Barru, Provinsi Sulawesi Selatan. Letak geografis Sulawesi Selatan antara $0^{\circ} 12^{\prime}-8^{\circ}$ Lintang Selatan dan $116^{\circ} 48^{\prime}-122^{\circ} 36^{\prime}$ Bujur Timur. Secara administratif berbatasan dengan Provinsi Sulawesi Barat dan Sulawesi Tengah di sebelah Utara, Sulawesi Tenggara di

2 Husni Mangga Barani, "Pemikiran Percepatan Pembangunan Perikanan Tangkap Melalui Gerakan Nasional," last modified 2004, diakses Oktober 15, 2019, http://www.rudyct.com/PPS702ipb/07134/husni_mb.pdf.

3 Robi Cahyadi, "Perancangan Alat Bantu Penangkap Ikan (Fishing Deck Machinery) untuk Peningkatan Produktifitas Nelayan," Prosiding Semnastek (2017): 2.

4 "Menteri Susi: Kerugian Akibat Illegal Fishing Rp 240 Triliun,” Detikcom, diakses Oktober 10, 2019, https://finance.detik.com/berita-ekonomi-bisnis/d-2764211/menteri-susi-kerugian-akibat-illegalfishing-rp-240-triliun. 
sebelah Timur, sedangkan di sebelah Barat dan Selatannya berbatasan dengan Selat Makassar dan Laut Flores. Posisi strategis yang dimiliki Provinsi Sulawesi Selatan yang berada pada persimpangan jalur lalu lintas penumpang, perdagangan barang dan jasa dari kawasan barat Indonesia (KBI) ke kawasan timur Indonesia (KTI). Provinsi yang juga dikenal dengan nama Gerbang Kawasan Timur Indonesia ini membagi wilayahnya menjadi 21 wilayah kabupaten dan 3 kota (Makassar, Palopo, Parepare).

Tabel 1. Pembagian Wilayah Administrasi Provinsi Sulawesi Selatan.

\begin{tabular}{|c|c|c|c|c|c|c|}
\hline \multirow{2}{*}{ No. } & \multirow{2}{*}{ Nama Daerah } & \multirow{2}{*}{ Luas Wilayah (Km2) } & \multicolumn{3}{|c|}{ Jumlah } & \multirow{2}{*}{ Ibu Kota } \\
\hline & & & Kec. & Kel. & Desa & \\
\hline 1. & Kepulauan Selayar & $1.357,03$ & 10 & 7 & 67 & Benteng \\
\hline 2. & Bulukumba & $1.284,63$ & 10 & 27 & 99 & Bulukumba \\
\hline 3. & Bantaeng & 395,83 & 8 & 21 & 46 & Bantaeng \\
\hline 4. & Jeneponto & 706,52 & 10 & 28 & 85 & Jeneponto \\
\hline 5. & Takalar & 566,61 & 9 & 20 & 57 & Takalar \\
\hline 6. & Gowa & $1.883,32$ & 18 & 44 & 123 & Sungguminasa \\
\hline 7. & Sinjai & 798,96 & 9 & 13 & 67 & Sinjai \\
\hline 8. & Bone & $4.559,00$ & 27 & 39 & 333 & Watampone \\
\hline 9. & Maros & $1.619,12$ & 14 & 23 & 80 & Maros \\
\hline 10. & Pangkajene Kepulauan & $1.132,08$ & 12 & 37 & 65 & Pangkajene \\
\hline 11. & Barru & $1.174,71$ & 7 & 14 & 40 & Barru \\
\hline 12. & Soppeng & $1.557,00$ & 8 & 21 & 49 & Watansoppeng \\
\hline 13. & Wajo & $2.504,06$ & 14 & 48 & 128 & Sengkang \\
\hline 14. & Sidenreng Rappang & $1.883,23$ & 11 & 38 & 67 & Sidenreng \\
\hline 15. & Pinrang & $1.961,67$ & 12 & 39 & 65 & Pinrang \\
\hline 16. & Enrekang & $1.784,93$ & 11 & 17 & 95 & Enrekang \\
\hline 17. & Luwu & $3.343,97$ & 21 & 15 & 177 & Belopa \\
\hline 18. & Tana Toraja & $1.990,22$ & 19 & 44 & 115 & Makale \\
\hline 19. & Luwu Utara & $7.502,58$ & 11 & 4 & 167 & Masamba \\
\hline 20. & Luwu Timur & $6.944,88$ & 11 & - & 99 & Maili \\
\hline 21. & Toraja Utara & $1.215,55$ & 21 & 43 & 108 & Rantepao \\
\hline 22. & Makassar & 199,26 & 14 & 143 & - & Makassar \\
\hline 23. & Parepare & 99,33 & 4 & 22 & - & Parepare \\
\hline \multirow[t]{2}{*}{24.} & Palopo & 252,99 & 9 & 48 & - & Palopo \\
\hline & Sulawesi Selatan & $46.717,48$ & 300 & 755 & 2.132 & Makassar \\
\hline
\end{tabular}

Berdasarkan kalkulasi berbagai wilayah di Sulawesi Selatan, data Balai Besar Karantina Ikan Pengendalian Mutu dan Keamanan Hasil Perikanan (KIPM) Makassar, menyatakan volume ekspor produk perikanan Sulawesi Selatan mengalami peningkatan signifikan pada periode Mei 2019 yang tercatat sebesar 15.089 ton dengan nilai mencapai 444,1 Miliar. Salah satu wilayah yang turut andil dalam peningkatan volume ekspor produk perikanan Sulawesi Selatan adalah Kabupaten Barru. Terkait wilayah kelautan Indonesia, Barru merupakan wilayah yang potensial. Sebagian besar masyarakatnya bekerja sebagai nelayan lokal.

Kabupaten Barru memiliki garis pantai sepanjang 78 km dengan kekayaan biota laut yang terkandung di dalamnya. Hal ini menjadikan sektor Perikanan/Perairan sebagai salah satu 
potensi penunjang kehidupan masyarakatnya, baik perikanan laut, pesisir, dan perikanan darat. Potensi pasar pun mendukung dengan peluang pasar ekspor maupun kebutuhan konsumsi ikan pada kebutuhan pangan masyarakat Barru.

Masyarakat Desa Siddo patut menjadi acuan dalam penggunaan metode penangkapan ikan dikarenakan masih mempertahankan tradisi penangkapan ikan yang bisa di anggap semi-tradisional untuk mencari tangkapan yaitu dengan menggunakan alat yang disebut $P a^{\prime}$ gae atau pukat cincin. Tim peneliti ingin mengkaji lebih lanjut mengenai kearifan lokal nelayan yang ada di Desa Siddo kaitannya peranan pemerintah daerah dalam menanggulangi kegiatan illegal fishing agar kekayaan alam yang terkandung di lautan dapat dipergunakan secara berkelanjutan dalam menunjang pembangunan perekonomian di Indonesia.

\section{Metode}

Jenis penelitian yang digunakan adalah penelitian sosio-legal yang dijabarkan secara deskriptif kualitatif. Penelitian sosio-legal, yaitu penelitian normatif yang didukung oleh data lapangan sebagai bahan pendukung, akan tetapi tetap merupakan studi terhadap norma-norma hukum tertulis. ${ }^{5}$ Penelitian dilaksanakan di Kabupaten Barru. Tempat penelitian, yaitu Pengadilan Negeri Kabupaten Barru, Dinas Kelautan dan Perikanan Kabupaten Barru, Kantor Kecamatan Soppeng Riaja Kabupaten Barru, Desa Siddo Kabupaten Barru, dan masyarakat nelayan Desa Siddo.

Informan ditentukan menggunakan teknik purposive sampling, yaitu penentuan informan yang dilakukan dengan pertimbangan tertentu. ${ }^{6}$ Informan dalam penelitian ini terdiri atas lima kategori, yaitu hakim yang pernah mengadili dan memutus perkara illegal fishing di Pengadilan Negeri Barru, Kepala Bidang Perizinan dan Pengaduan Dinas Perikanan yang menangani pelaporan di Dinas Perikanan Kabupaten Barru, Kepala Seksi Perekonomian dan Pembangunan di Kantor Kecamatan Soppeng Riaja Kabupaten Barru, Kepala Seksi Pelayanan Kantor Desa Siddo Kabupaten Barru, dan beberapa kelompok nelayan-nelayan Desa Siddo.

Berdasarkan hasil pengumpulan data, maka selanjutnya dilakukan pengolahan data. Data yang diperoleh akan dikategorikan sesuai jenis datanya. Kemudian data tersebut akan dianalisis dengan menggunakan metode kualitatif, yaitu menganalisis data yang berhubungan dengan masalah yang diteliti, kemudian dipilih berdasarkan pikiran yang logis untuk menghindarkan kesalahan dalam proses analisis data. Hasil yang diperoleh akan dipaparkan secara deskriptif, yaitu dengan menguraikan, menjelaskan, dan menggambarkan sesuai permasalahan dalam penelitian ini. Penarikan kesimpulan dilakukan berdasarkan hasil analisis dari data wawancara mendalam (Indepth Interview)

5 Sulistyowati Irianto dan Sidharta, Metode Penelitian Hukum: Konstelasi dan Refleksi (Jakarta: Yayasan Obor Indonesia, 2011), 177.

6 Sugiyono, Metode Penelitian Kuantitatif Kualitatif dan R\&D (Bandung: CV. Alfabeta, 2010), 122. 
dan data kepustakaan dengan melakukan interpretasi atau penafsiran terhadap informasi yang diperoleh.

\section{Bentuk dan Intensitas Illegal Fishing di Desa Siddo Kabupaten Barru}

Secara umum, definisi illegal fishing adalah aktivitas penangkapan ikan yang dilakukan oleh armada penangkapan asing atau armada nasional di wilayah teritorial atau Zona Ekonomi Eksklusif Indonesia (ZEEI) tanpa izin atau bertentangan dengan peraturan perundang-undangan yang berlaku. Berdasarkan definisi tersebut dapat dipahami bahwa illegal fishing berarti penangkapan ikan yang dilakukan dengan melanggar aturan yang ada. ${ }^{7}$ Salah satu hal yang menjadi perhatian dalam penangkapan ikan adalah metode dan teknologi penangkapan yang ramah lingkungan sesuai dengan prinsip-prinsip perikanan yang rasional dan bertanggung jawab.

Provinsi Sulawesi Selatan menjadi salah satu wilayah yang memikat untuk melakukan illegal fishing dengan potensi sumber kekayaan laut yang sangat melimpah. Cukup banyak kasus illegal fishing yang telah ditangkap basah oleh pihak berwajib. Beragam kasus illegal fishing terjadi, mulai dari pengeboman ikan, penggunaan bahan berbahaya, dan tindakan tak bertanggungjawab lainnya yang masih kerap ditemukan. Salah satu faktor yang melatarbelakangi kasus illegal fishing adalah sifat tamak manusia untuk menguras kekayaan laut tanpa mempertimbangkan imbas dari kerusakan lingkungan yang ditimbulkan.

Data Dinas Kelautan dan Perikanan Sulawesi Selatan dari tahun 2009 sampai 2016, menunjukkan angka illegal fishing yang kian meningkat setiap tahunnya. Meski telah ditangani oleh pihak berwajib, tetapi pemerintah masih berhasil dikelabuhi oleh pihakpihak tidak bertanggungjawab. Hal ini dapat diketahui dengan, melihat diagram di bawah ini:

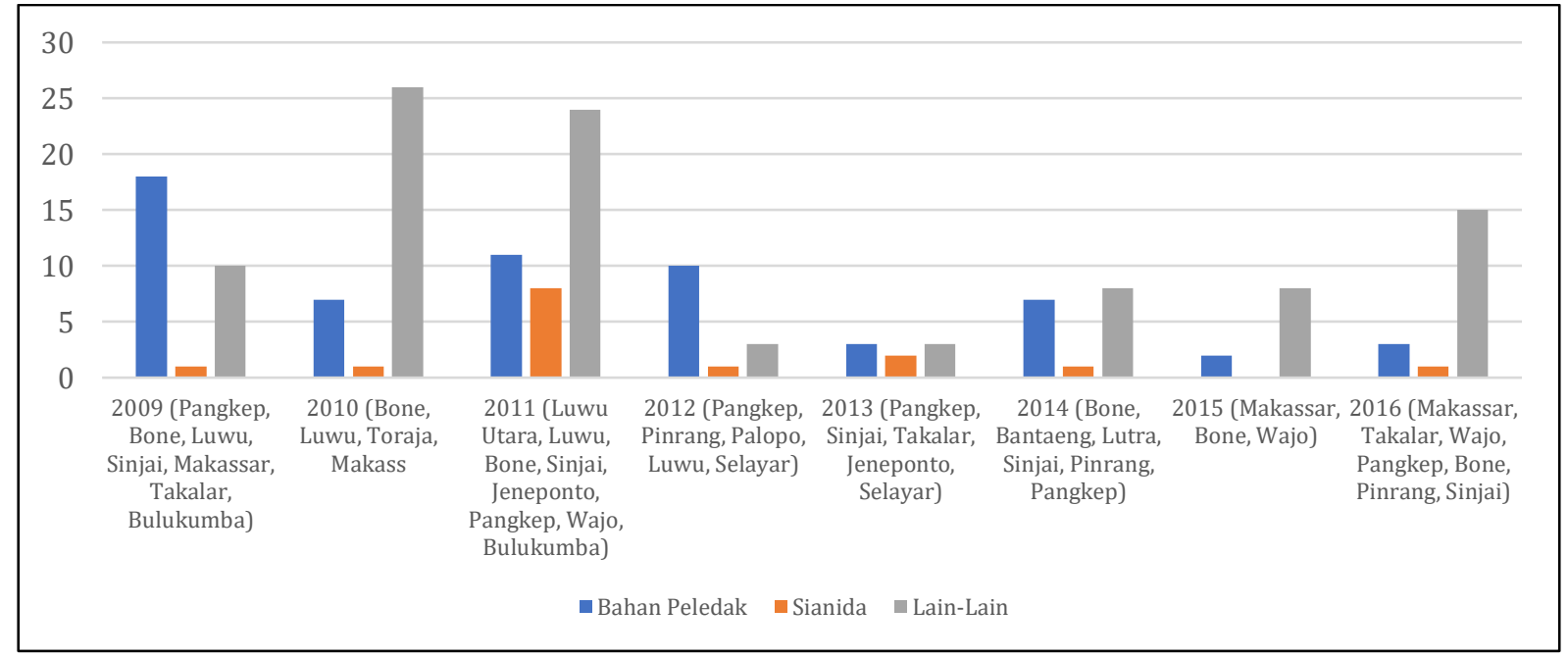

Gambar 1. Diagram Kasus Illegal Fishing Sulawesi Selatan Tahun 2009-2016.

7 Arifin Neka, "Analisis Kebijakan Penanggulangan Illegal Fishing di Kabupaten Halmahera Utara" (Sekolah Pascasarjana Institut Pertanian Bogor, 2010), 10. 
Terlihat fluktuasi kegiatan illegal fishing yang terjadi di Sulawesi Selatan berdasarkan data Dinas Kelautan dan Perikanan Sulawesi Selatan yang dihimpun dari hasil pengungkapan yang dilakukan pihak berwajib. Data yang tertera di atas hanya merupakan bagian kecil kasus yang terungkap, masih banyak kasus kejadian lainnya yang tidak ditemukan. Upaya pihak berwajib telah dioptimalkan, namun ternyata penanganan kasus illegal fishing memang cukup sulit. Beberapa faktor yang menjadi alasan terkendalanya penanganan di antaranya adalah kurangnya alat bukti, ataupun faktor pelaku kejahatan yang sulit untuk ditangkap dan telah melakukan upaya pelarian diri sebelum pihak berwajib berhasil menangkapnya. Selain faktor yang berasal dari aparat keamanan, faktor lain seperti kurangnya pemahaman nelayan soal batas jalur tangkap juga menjadi alasan kasus ini terus menerus menjadi mata rantai tanpa putus.

Salah satu bentuk illegal fishing yang kerap terjadi adalah penggunaan metode dan/ atau teknologi yang dilarang oleh Undang-Undang misalnya penggunaan bahan peledak, sianida, pukat harimau, dan bahan-bahan lain yang menimbulkan kerusakan lingkungan laut. Undang-Undang sebenarnya secara tegas telah melarang penggunaan alat tangkap tersebut, namun adanya payung hukum saja ternyata belum mampu memberikan efek jera kepada pelaku. Kurangnya pemahaman masyarakat terhadap pentingnya menjaga keanekaragaman hayati laut diduga menjadi pemicu masih banyaknya kasus illegal fishing yang terjadi.

Beberapa daerah di Sulawesi Selatan menjadi sasaran strategis untuk melancarkan kegiatan illegal fishing, salah satunya Kabupaten Pangkep. Berdasarkan data di atas setiap tahunnya Kabupaten Pangkep hampir tidak pernah absen dalam menangani kasus illegal fishing. Bahkan pemerintah terkesan gagal dalam memberikan contoh kepada pelaku kejahatan illegal fishing lainnya untuk menghentikan kegiatan yang melanggar hukum tersebut.

Berbeda halnya dengan Kabupaten Barru yang juga terletak di Provinsi Sulawesi Selatan menjadi salah satu wilayah yang memiliki tingkat kasus terendah atau sangat kecil. Di antara 21 wilayah dan 3 kota, Kabupaten Barru menjadi salah satu wilayah rendah terhadap catatan kasus illegal fishing dibandingkan dengan beberapa wilayah lainnya yang tercatat sering mendapat kasus praktik illegal fishing di perairannya. Hal ini pun sejalan dengan masyarakat Barru bermata pencaharian nelayan yang masih menjunjung tinggi nilai kearifan leluhurnya dalam pengaplikasian penangkapan ikan.

Salah satu wilayah di Kabupaten Barru yang minim tindakan illegal fishing adalah Desa Siddo. Kearifan lokal menjadi cara melaut tradisional yang hingga kini masih terus dipertahankan secara turun-temurun. Nelayan mencari nafkah dengan memperhatikan dan menjaga kelestarian lingkungan. Secara sederhana nelayan melakukan penangkapan ikan hanya untuk memenuhi kebutuhan sehari-hari dalam ruang lingkup keluarganya. Hal inilah yang diharapkan dapat menjadi prinsip yang juga ditekankan oleh nelayan-nelayan lain untuk menghindari tindakan illegal fishing yang akhirnya merugikan bagi kelestarian lingkungan. Tim peneliti mengambil sampel daerah pesisir pantai di Desa Siddo Kecamatan Soppeng Riaji Kabupaten Barru sebagai objek sasaran penelitian ini. Desa ini 
dapat dijadikan contoh minimnya praktik illegal fishing dengan kearifan lokal yang masih diterapkan.

Narasumber yang menjadi responden peneliti ialah 3 komunitas nelayan yang menggunakan metode penangkapan ikan dengan memakai pukat cincin, bertempat tinggal di pesisir pantai Desa Siddo Kecamatan Soppeng Riaja Kabupaten Barru. Beberapa responden yang memberikan keterangan menyatakan bahwa mereka berprofesi sebagai seorang nelayan bukan karena bertempat tinggal di pesisir pantai. Melainkan pilihan tersebut secara sukarela mereka lakukan sebagai bentuk meneruskan tradisi orang tua yang telah turun temurun berprofesi sebagai seorang nelayan di daerah tersebut.

Warga juga menuturkan hambatan yang kerap dihadapi saat hendak melaut terutama mengenai cuaca. Berbagai kerusakan alam yang mengakibatkan bergesernya musim dan cuaca, menyebabkan musim kian sulit diprediksi. Menurut kesaksian nelayan di Desa Siddo Kecamatan Soppeng Riaja Kabupaten Barru yang juga bergantung pada musim menyatakan jadwal melautnya. Biasanya pada musim hujan yang disertai angin barat, yang berlangsung antara bulan November hingga Januari, hasil tangkapan sangat kurang. Pada masa ini, nelayan biasanya melaut hanya sekedar untuk memenuhi kebutuhan rumah tangganya, mengingat risiko yang dibawa oleh musim penghujan kepada nelayan yang tetap pergi melaut sangat berbahaya. Antara bulan Juni sampai dengan Oktober, terutama ketika malam gelap setelah bulan purnama, hasil tangkapan melimpah. Pada masa ini, angin berhembus dari timur sehingga laut relatif tenang dan juga intensitas turunnya hujan akan lebih berkurang atau bahkan tanpa hujan. Ketika malam gelap tanpa bulan, lampu yang berada bagan betul-betul efektif menarik ikan untuk berkumpul di sekitarnya. Antara Februari hingga Mei hasil tangkapan berada pada tingkat rata-rata.

Kegiatan Illegal Fishing di Kabupaten Barrumasih sangat minim tidak sebanyak daerah lain. Hal ini dapat dilihat dari data yang menunjukkan sepanjang tahun 2018 hanya ada satu kasus perikanan yang ditangani oleh Pengadilan Negeri Barru, yakni kasus dengan Nomor Putusan 13/Pidsus/2019. Kasus posisinya adalah penangkapan ikan dengan menggunakan thrawl yang dilakukan oleh oknum nelayan di Desa Corowali Kecamatan Tanete Rilau ${ }^{8}$.

Dalam menghadapi atau menangani kasus Illegal Fishing, Pengadilan Negeri Barru tidak memiliki panduan khusus institusi pengadilan yang dikeluarkan secara resmi oleh lembaga. Semua berpatokan pada aturan perundang-undangan terkait perikanan dan melihat kondisi sosial ekonomi masyarakat nelayan sebagai bahan pertimbangan. Aturan terkait Illegal Fishing dianggap sudah cukup memadai hanya perlu rutin dilakukan sosialisasi agar informasi ini sampai kepada masyarakat nelayan. Selama ini, nelayan hanya tahu bahwa aktivitas Illegal Fishing dilarang namun hanya sedikit yang memahami adanya ancaman pidana yang diberikan jika melakukan hal tersebut ${ }^{9}$.

8 Hasil wawancara dengan Bapak Arief Fatony selaku Hakim di Pengadilan Negeri Barru 9 Ibid. 
Pada tanggal 11 Desember 2018 terjadi kegiatan illegal fishing di wilayah Desa Lasitae Kabupaten Barru. Kegiatan illegal fishing ini dilakukan oleh bapak (U) dan anak (D) yang sehari-hari bekerja sebagai nelayan. Terdakwa menggunakan trawl yang tergolong kecil dengan jaring berukuran 15 meter dan 2 buah pemberat berukuran panjang $1 \mathrm{M}$ dan lebar $50 \mathrm{~cm}$. Larangan penggunaan trawl telah diatur dalam Peraturan Menteri Kelautan dan Perikanan No. 2/PERMEN-KP/2015 karena dapat merusak terumbu karang dan biota laut lainnya sehingga ekosistem laut dapat terganggu. Oleh karena itu, terdakwa langsung ditindak tegas oleh pihak kepolisian setempat dan dituntut 5 bulan penjara berdasarkan Pasal 85 Undang-Undang Nomor 45 Tahun 2009 tentang perubahan atas Undang-Undang Nomor 31 Tahun 2004 tentang Perikanan yang menyatakan:

"Setiap orang dengan sengaja memiliki, menguasai, membawa dan atau menggunakan alat penangkapan ikan dan/atau alat bantu penangkapan ikan yang tidak sesuai dengan persyaratan, atau standar yang ditetapkan untuk tipe alat tertentu, dan atau alat penangkap ikan yang dilarang dipidana dengan pidana penjara paling lama 5 (lima) tahun dan denda paling banyak Rp.2.000.000.000,- (dua milyar rupiah)".

Dalam acara pemeriksaan, terdakwa mengakui menggunakan trawl untuk menangkap ikan. Cara penggunaannya dengan melempar jaring yang di bawahnya diberi pemberat berupa kayu dan di atasnya diberi kayu sebagai pelampung kemudian ditarik dengan perahu dan dibiarkan selama 2 (dua) jam. Setelah itu, jaring ditarik dengan menggunakan tangan dan ikannya diambil. Akan tetapi, terdakwa menyatakan bahwa ia tidak mengetahui bahwa penggunaan trawl dilarang sehingga ia masih menggunakannya. Alasan ketidaktahuan terdakwa tentang pelarangan penggunaan trawl tidak dapat dibenarkan berdasarkan asas fiksi hukum ${ }^{10}$ untuk itu terdakwa harus bertanggung jawab atas tindakannya. Dengan mempertimbangkan bahwa terdakwa merupakan nelayan kecil yang tidak masuk dalam kelompok nelayan, kapal yang digunakan termasuk kapal kecil berukuran 10 x 1,8 M serta alat tangkap berupa trawl mini sehingga hasil tangkapan ikan yang didapatkan tidak banyak dan kerusakan ekosistem laut yang ditimbulkan juga kecil maka majelis hakim Pengadilan Negeri Barru memutuskan untuk menjatuhkan hukuman 3 bulan penjara kepada terdakwa. Kemudian alat tangkap yang digunakan berupa trawl dirampas untuk dimusnahkan sementara kapal dikembalikan kepada terdakwa.

Hal ini sejalan dengan wawancara yang dilakukan dengan ketua komunitas nelayan bahwa mereka tidak pernah memiliki hubungan dengan aparat penegak hukum dalam melakukan kegiatan sehari-hari sebagai nelayan. Pernyataan ini juga diakui oleh beberapa nelayan yang turut kami wawancarai bahwa mereka hanya berkomunikasi dan berkoordinasi dengan pihak instansi pemerintah apabila hal itu terkait kegiatan sosialisasi di bidang perikanan ataupun ada bantuan yang diberikan oleh pemerintah.

10 Asas fiksi hukum menyatakan bahwa semua orang dianggap tahu hukum (presumptio iures de iure) artinya meskipun seseorang belum pernah membaca suatu aturan hukum tetapi ketika ia melakukan tindakan yang bertentangan dengan hukum maka ketidaktahuannya tidak dapat dijadikan alasan untuk membenarkan tindakannya. 


\section{Peranan Kearifan Lokal Nelayan Dalam Upaya Penanggulangan Illegal Fishing di Desa Siddo Kabupaten Barru}

Kebudayaan Pa'gae adalah teknik penangkapan ikan secara tradisional yang telah turun temurun dilakukan oleh masyarakat Desa Siddo Kecamatan Soppeng Riaja Kabupaten Barru. Teknik ini di Indonesia pada umunya disebut pukat cincin, tetapi bagi masyarakat desa Siddo sendiri teknik ini disebut Pa'gae. Sebutan "gae" adalah sebutan akrab yang mengartikan pukat cincin untuk wilayah perairan pantai barat Sulawesi Selatan bagian utara. Kebudayaan ini telah dilakukan sejak tahun 1970-an oleh masyarakat desa Siddo yang merupakan modernisasi dari teknik penangkapan sebelumnya yang hanya menggunakan jala. Pukat cincin adalah salah satu alat tangkap ikan yang digolongkan dalam kelompok jaring lingkar (surrounding nets).

Secara umum $P a^{\prime}$ gae sangat ramah lingkungan dan menjaga kelangsungan plasma nutfah di wilayah perairan laut desa Siddo, karena dari ukuran jaring yang digunakan hanya mampu menangkap ukuran ikan yang diatur di dalam Peraturan Menteri Kelautan dan Perikanan No. 35 Tahun 2009 tentang Tata Cara Penetapan Status Perlindungan Jenis Ikan dan Permen Kelautan dan Perikanan No.42/PERMEN-KP/2014 Tentang Jalur Penangkapan Ikan dan Penempatan Alat Penangkapan Ikan dan Alat Bantu Penangkapan Ikan di Wilayah Pengelolaan Perikanan Negara Republik Indonesia.

Alat tangkap tersebut dioperasikan menggunakan motor temel dan body sebagai sarana pelengkap, untuk meningkatkan efisiensi dan efektivitas penangkapan. Maka dalam pengoperasian pukat cincin ini biasanya menggunakan cahaya dan rumpon untuk mengumpulkan ikan pada area penangkapan. ${ }^{11}$ Alat tangkap pukat cincin ini dapat menangkap ikan hingga kedalaman 150 meter tergantung ukuran dan konstruksi jaring. Secara garis besar alat ini terdiri dari beberapa bagian, yaitu jaring, pelampung, pemberat, cincin, dan tali temali. Konstruksi jaringnya berbeda yang terdiri dari bagian kantong, bahu dan sayap. Ukuran mata jaringnya berbeda yaitu berupa tali pelampung dan pemberat yang digunakan untuk memasang pelampung, tali ris atas dan tali ris bawah yang terletak di atas dan di bawah jaring serta tali cincin yang biasa dikenal dengan tali kolor yang terdapat di dalam cincin. Apabila ditarik maka cincin akan terkumpul sehingga jaring mengerut membentuk kantong dan mengurung gerombolan ikan. ${ }^{12}$

A.U. Ayodhyoa, Metode Penangkapan Ikan (Bogor: Yayasan Dewi Sri, 1981), 97.

12 Martha Masrun, Nurdin Jusuf, dan Otniel Pontoh, "Kontribusi Usaha Pukat Cincin (Purse Seine) terhadap Penyerapan Tenaga Kerja di Kelurahan Tumumpa Dua Kecamatan Tuminting Kota Manado Provinsi Sulawesi Utara," AKULTURASI: Jurnal Ilmiah Agrobisnis Perikanan 5, no. 9 (2017): 565. 


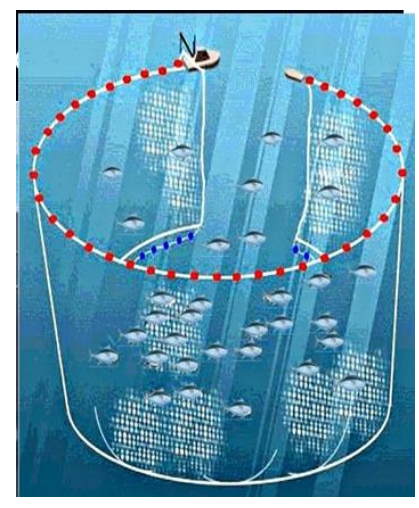

Gambar 2. Ilustrasi Pukat Cincin.

Para nelayan di Desa Siddo ketika ingin melaut memperhatikan kondisi bulan untuk menentukan waktu yang tepat memasangkan Pa'gae-nya. Ketika kondisi bulan dalam keadaan purnama, hasil tangkapan para nelayan tidak sebanyak ketika kondisi bulan dalam keadaan tidak purnama karena ketika intensitas cahaya terang, ikan dapat melihat dengan jelas kondisi di bawah air sehingga dapat menghindari Pa'gae yang disebar nelayan. Para nelayan mulai turun melaut menggunakan $P a^{\prime} g a e$ ketika anak buah kapal mencukupi minimal 15 orang karena penggunaan $\mathrm{Pa}^{\prime}$ gae itu memerlukan banyak tenaga dalam penggunaannya.

Pertama, para nelayan mempersiapkan bekalnya masing-masing sebelum melakukan penangkapan karena waktu yang cukup lama berada di lautan. Pada musim panen sesuai yang telah dijelaskan di bagian sebelumnya nelayan berangkat ke laut pada pukul 15.0016.00 Wita sampai pada pukul 04.00-05.00 Wita menggunakan 2 kapal, yakni kapal induk sebagai tempat transportasi awak kapal dalam melakukan penangkapan dan kapal sampan yang dipenuhi dengan lampu sebagai kapal penarik perhatian ikan yang di letakan di tengah bagan Rambo.

Kedua, setelah merasa sudah cukup jauh dari bibir pantai, terlebih dahulu melakukan eksplorasi lingkungan perairan guna menentukan lokasi yang tepat untuk menebar bagannya. Dalam menebarkan bagan mereka mulai bekerja sesuai dengan pembagian pekerjaan yang telah dibagikan, antaranya:

1. Menebar jaring sekitar 10-15 orang dengan tingkat kerapatan jaring $>1$ inci berukuran bagan 20 x 20 meter persegi berbentuk lingkaran.

2. Memasang lampu penerangan (dulunya menggunakan lampu petromax, dimodernisasi dengan menggunakan lampu berenergi genset) di tiap titik-titik strategis diwilayah bagan guna memancing ikan ke arah bagan.

3. Yang membawa kapal sampan 2 orang, yang akan membawa kapal tersebut ke tengah bagan yang telah disebar.

4. Sebagai pengarah dalam hal ini adalah punggawa kapal.

Secara konsepsional kearifan lokal yang berkembang di Indonesia atau yang lebih dikenal dengan Hak Ulayat Laut (HUL) merupakan terjemahan dari bahasa Inggris, sea tenure. Seorang pakar kelautan, Laundsgaarde menyebutkan bahwa istilah sea tenure mengacu 
kepada seperangkat hak dan kewajiban timbal balik yang muncul dalam hubungannya dengan kepemilikan wilayah laut. Selanjutnya Sudo (1983) mengatakan bahwa sea tanure merupakan suatu sistem, di mana beberapa orang atau kelompok sosial memanfaatkan wilayah laut, mengatur tingkat eksploitasinya termasuk melindunginya dari eksploitasi yang berlebihan (over exploitation). Oleh karena itu melengkapi batasan Sudo, Akimido (1991) mengatakan bahwa hak-hak kepemilikan (property rights), mempunyai konotasi sebagai memiliki (to own), memasuki (to access), dan memanfaatkan (to use).

Kearifan lingkungan dapat diwujudkan dalam nilai sosial, norma adat, etika, sistem kepercayaan, pola penataan ruang tradisional, serta peralatan dan teknologi sederhana ramah lingkungan. Sumber daya sosial yang diwarisi secara turun temurun tersebut, pada kenyataannya terbukti efektif menjaga kelestarian lingkungan, serta menjamin kelestarian lingkungan sosial. Konotasi semacam ini tidak hanya mengacu pada wilayah penangkapan (fishing ground), tetapi juga mengacu pada teknik-teknik penangkapan, peralatan penangkapan, teknologi yang digunakan bahkan sumber daya yang ditangkap dan dikumpulkan.

Dalam konteks hukum nasional, pengelolaan perikanan berbasis kearifan lokal mendapatkan pengakuan secara nyata dalam perundang-undangan, di antaranya ${ }^{13}$ :

Tabel 2. Peraturan Pengakuan Hak Ulayat dalam Pengelolaan Perikanan.

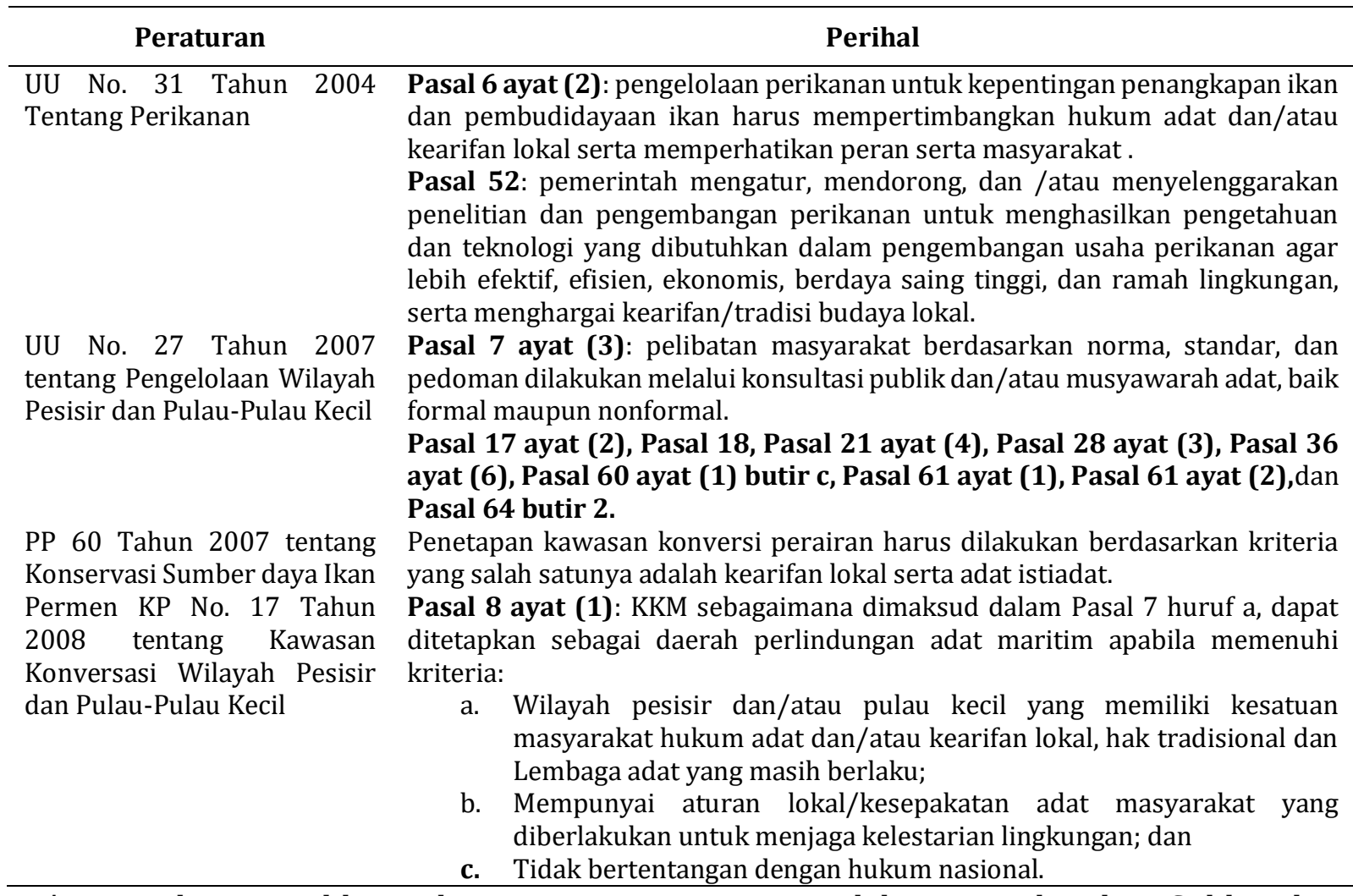

Pa'gae sendiri terus dilestarikan secara turun temurun oleh masyarakat desa Siddo selain karena sebagai teknik penangkapan ikan yang digunakan oleh masyarakat setempat

${ }^{13}$ Luky Adrianto, Konstruksi Pengelolaan Sumberdaya Perikanan di Indonesia (Bogor: IPB Press, 2011), 1215. 
dalam mencari nafkah, $P a^{\prime} g a e$ juga dijadikan oleh masyarakat desa Siddo sebagai alat guna mempererat silaturahmi antar masyarakat, yang dapat ditunjukkan dari sikap gotong royong serta merangkul masyarakat sekitar sebagai sumber tenaga kerja yang diperbantukan nelayan-nelayan desa Siddo. Bisa dilihat dari kebutuhan ABK dari setiap kapal ketika ingin melaut membutuhkan sedikitnya 10 orang ABK yang ditugaskan untuk menebar dan mengangkat jaring dengan kerapatan>1 inci seluas 20x20 meter persegi berbentuk lingkaran. Penggunaan kerapatan jaring ini sesuai dengan kriteria alat penangkapan ikan yang diatur dalam Permen Kelautan dan Perikanan No.42/PERMENKP/2014 tentang Jalur Penangkapan Ikan dan Penempatan Alat Penangkapan Ikan dan Alat Bantu Penangkapan Ikan di Wilayah Pengelolaan Perikanan Negara Republik Indonesia ${ }^{14}$ sehingga menjamin kelestarian plasma nutfah di dalamnya tetap terjaga, karena ikan berukuran kecil yang merupakan cadangan ketersediaan ikan dimasa yang akan datang, tidak ikut terjaring.

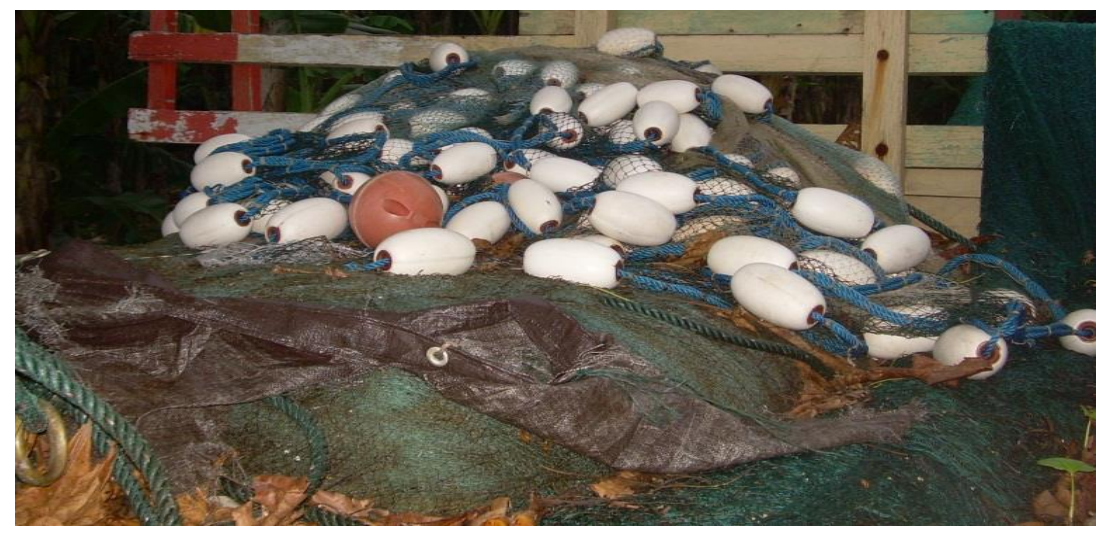

Gambar 3. Alat Penangkapan Ikan Pukat Cincin.

Penggunaan pukat cincin diakui nelayan masih tergolong ramah lingkungan karena tidak merusak karang dan adanya selektivitas jaring dalam menangkap ikan. Hanya ikan besar saja yang bisa masuk dalam jaring ${ }^{15}$. Data ini sejalan dengan analisis tingkat keramahan penggunaan pukat cincin berdasarkan penelitian yang dilakukan oleh GTO yang menunjukkan indikator sebagai berikut:

1. Selektivitas mata jaring

Alat tangkap pukat cincin (purse seine) hanya ramah pada ikan selar dan ikan layang.

2. Penggunaan BBM

Penggunaan bahan bakar minyak (BBM) pada pukat cincin (purse seine) masih tergolong sedang.

3. By-catch (discards) rendah

Jumlah discards pada pukat cincin (purse seine) sangat rendah yaitu 1\%, sehingga purse seine tergolong ramah terhadap lingkungan.

14 Pasal 22 (1) Peraturan Menteri Kelautan dan Perikanan Nomor 42/PERMEN-KP/2014 Tentang Perubahan Keempat Atas Peraturan Menteri Kelautan dan Perikanan Nomor Per.02/Men/2011 Tentang Jalur Penangkapan Ikan Dan Penempatan Alat Penangkapan Ikan Dan Alat Bantu Penangkapan Ikan Di Wilayah Pengelolaan Perikanan Negara Republik Indonesia

15 Berdasarkan Hasil Wawancara dengan Arif, Nelayan Desa Siddo. 


\section{Hasil tangkapan segar}

Sesuai dengan hasil penelitian menunjukkan bahwa hasil tangkapan dari alat tangkap purse seine masih tergolong segar.

5. Tidak merusak habitat

Dampak alat tangkap purse seine terhadap habitat, dikategorikan ramah terhadap lingkungan. Karena alat tangkap purse seine tidak mengganggu habitat, khususnya habitat karang.

Minimnya dampak yang dihasilkan dari penggunaan pukat cincin sebagai metode penangkapan ikan oleh masyarakat, hal ini dapat dijadikan sebagai salah satu acuan referensi oleh nelayan lainnya untuk menggunakan metode yang sama. Bahwasanya pukat cincin pun tidak menimbulkan kerugian pada nelayan, yang mana nelayan dapat tetap beroperasi dengan sistem yang tentunya telah dilegalkan perundang-undangan di Indonesia, dan selain itu tetap ramah lingkungan. Sehingga secara tidak langsung andil dari nelayan yang menggunakan metode ramah lingkungan dalam menangkap ikat turut serta melestarikan kearifan lokal serta menjaga ekosistem tetap seimbang tanpa adanya perusakan alam.

Nilai-nilai kearifan lokal yang masih dijunjung tinggi masyarakat Nelayan Siddo membuat para nelayan tidak tergiur untuk melakukan cara-cara yang ilegal dalam menangkap ikan. Misal menggunakan, tharwl, bom ikan dan sejenisnya. Nelayan sadar bahwa cara ini akan merusak ekosistem laut yang akan berdampak pada penghasilan mereka juga nantinya. Sehingga nelayan di desa Siddo tetap memilih menggunakan pukat cincin sebagai metode dalam menangkap ikan.

Cara berpikir yang mungkin dikategorikan sebagai metode tradisional, nyatanya didukung oleh pemerintah Indonesia melalui Peraturan Menteri Kelautan dan Perikanan Republik Indonesia No.71/PERMEN-KP/2016 Tentang Jalur Penangkapan Ikan dan Alat Penangkapan Ikan di Wilayah Pengelolaan Perikanan Negara Republik Indonesia Bab III Pasal 6. Aturan hukum di Indonesia telah menimbang dan menimang dari berbagai sisi positif maupun negatif kebijakan yang nantinya menguntungkan bagi bangsa dan Negara Indonesia.

Nelayan Desa Siddo ternyata selain dapat mempererat silaturahmi antar masyarakatnya dengan Pa'gae juga memiliki ritual adat sendiri dalam menangkap ikan. Maccera Tasi' adalah sebuah tradisi dimana nelayan memotong hewan yang kemudian dimasak dan diolah. Hasil masakan dibawa melaut dan dimakan secara bersama-sama di laut. Tujuan dari tradisi ini adalah sebagai wujud syukur atas hasil tangkapan dan berharap semoga ekosistem laut senantiasa terjaga sehingga nelayan mendapatkan ikan yang melimpah ${ }^{16}$.

Pada sistem kearifan lokal nelayan desa Siddo tidak ada aturan yang tertulis antara nelayan dan pemerintah setempat, namun mayoritas nelayan Siddo memahami bahwa dalam melakukan aktivitas penangkapan ikan tidak diperbolehkan menggunakan bom

16 Hasil Wawancara dengan Muis, Nelayan Desa Siddo 
ikan, trawl, pukat harimau dan alat lain yang bisa merusak dan mengganggu ekosistem laut. Mencari rezeki dengan memperhatikan lingkungan sekitar sudah menjadi salah satu adat/kebiasaan yang mereka lestarikan. Meskipun dijelaskan di atas dengan latar belakang pendidikan rendah, bahkan buta akan hukum terkait sanksi pidana yang dapat dikenakan terhadap aktivitas laut yang merusak, masyarakat desa Siddo nyatanya telah menggunakan hukum-hukum tersebut jauh dari kata mengetahui hukum yang sedang berlaku.

Realitasnya kini masyarakat meski dibentengi dengan norma-norma dan hukum yang menjulang tinggi, tetapi ketamakan menjadi faktor utama pendorong masyarakat tersebut untuk tidak mematuhi hukum. Meski demikian, masyarakat desa Siddoro menggambarkan hal yang sebaliknya. Walaupun memang nyatanya buta akan hukum yang tengah mengatur seputar kegiatannya, tetapi dengan kesadaran akan kebutuhan pada alam yang tidak akan pernah berhenti baik bagi dirinya sampai dengan keturunan selanjutnya, sehingga memberikan sensitivitas untuk peduli terhadap lingkungan yang mereka naungi. Kesadaran masyarakat nelayan desa Siddo yang tidak tergiur atau tertarik menggunakan teknologi modern yang dilarang, tetap bertahan dengan hasil apa pun yang diperoleh menjadi salah satu wujud peranan kearifan lokal dalam menanggulangi Illegal Fishing.

\section{Peran Pemerintah dalam menindaklanjuti Illegal Fishing di Desa Siddo Kabupaten Barru}

Pemberantasan illegal fishing adalah salah satu upaya penyelamatan Sumber Daya Ikan (SDI) di laut. Kegiatan mengeksploitasi sumber daya alam laut, sangat rentan akan rusaknya lingkungan laut yang mana hal ini dapat disebabkan oleh cara penangkapan yang merusak atau tidak ramah lingkungan dan segala aktivitas lainnya yang merugikan belum lagi kondisi seperti ini akan menciptakan munculnya konflik-konflik sosial dalam masyarakat. Oleh karena itu, perlu adanya regulasi atau aturan yang mengatur yang dibuat oleh negara dalam hal ini pemerintah.

Regulasi atau aturan negara tersebut telah menjadi hukum sebagai pranata kehidupan sosial masyarakat atau sebagai suatu institusi yang berlangsung dalam masyarakat, menerima asupan-asupan (sengketa atau konflik) dari bidang ekonomi, politik dan budaya yang terjadi dalam masyarakat, dengan kata lain hukum tersebut mempunyai makna sebagai alat kontrol sosial dalam kehidupan masyarakat.

Undang-Undang Nomor 45 Tahun 2009 tentang Perubahan Atas Undang-Undang Nomor 31 Tahun 2004 tentang Perikanan menyebutkan bahwa:

"Setiap orang dilarang memiliki, menguasai, membawa, dan/atau menggunakan alat penangkapan ikan dan/atau alat bantu penangkapan ikan yang mengganggu dan merusak keberlanjutan sumber daya ikan di kapal penangkap ikan di wilayah pengelolaan perikanan Republik Indonesia. Apabila diketahui dan didapatkan cukup bukti terdapat oknum masyarakat yang melakukan kegiatan penangkapan 
ikan dengan cara merusak, maka dapat dikenakan sanksi pidana penjara paling lama 5 tahun atau denda paling banyak Rp. 2 milyar"

Berkaitan dengan aturan penggunaan alat penangkap ikan juga ditegaskan dalam ketentuan Pasal 9 Ayat (1) Undang-Undang Nomor 45 Tahun 2009 Tentang Perikanan yang menyebutkan bahwa:

"Setiap orang dilarang memiliki, menguasai, membawa, dan/atau menggunakan alat penangkapan dan/atau alat bantu penangkapan ikan yang mengganggu dan merusak keberlanjutan sumber daya ikan di kapal penangkap ikan di wilayah pengelolaan perikanan Negara Republik Indonesia"

Tidak hanya itu, pemerintah juga mengeluarkan pengaturan alat penangkapan ikan sebagai berikut:

Tabel 3. Peraturan Alat Penangkapan Ikan.

\begin{tabular}{|c|c|}
\hline Tanggal & Peraturan \\
\hline 11 Januari 2010 & $\begin{array}{l}\text { KEPMEN No.KEP.06/MEN/2010 tentang Alat Penangkapan Ikan di Wilayah } \\
\text { Pengelolaan Perikanan Negara Republik Indonesia }\end{array}$ \\
\hline 31 Januari 2011 & $\begin{array}{l}\text { PERMEN No.PER.02/MEN/2011 tentang Jalur Penangkapan Ikan dan Alat } \\
\text { Bantu Penangkapan Ikan di WPPNRI yang diubah sebanyak } 5 \text { kali }\end{array}$ \\
\hline 8 Januari 2015 & $\begin{array}{l}\text { PERMEN No.2/PERMEN-KP/II/2016 tentang Larangan Penggunaan Alat } \\
\text { Penangkapan Ikan Pukat Hela (Trawls) dan Pukat Tarik (Seine Nets) di WPPNRI }\end{array}$ \\
\hline 25 Juni 2015 & $\begin{array}{l}\text { Rekomendasi Ombudsman No.0006/REK/0201.2015/PBP-24/VI/2015 } \\
\text { tentang memberikan masa waktu transisi implementasi peraturan pada poin } 3 \\
\text { sekurang-kurangnya dua tahun }\end{array}$ \\
\hline 11 Februari 2016 & $\begin{array}{l}\text { Surat Edaran No. 72/MEN-KP/II/2016 tentang Pembatasan Penggunaan Alat } \\
\text { Penangkapan Ikan Cantrang di WPPNRI } \rightarrow \text { sampai Desember } 2016\end{array}$ \\
\hline 30 Desember 2016 & $\begin{array}{l}\text { PERMEN No.71/ PERMEN-KP/2016 tentang Jalur Penangkapan Ikan dan } \\
\text { Penempatan Alat Penangkapan Ikan di WPPNRI }\end{array}$ \\
\hline 3 Januari 2017 & $\begin{array}{l}\text { Surat Edaran No.B.1/SJ/PL.610/I/2017 tentang Pendampingan Penggantian } \\
\text { Alat Penangkapan Ikan yang Dilarang Beroperasi di WPPNRI } \rightarrow \text { s/d } 30 \text { Juni } \\
2017\end{array}$ \\
\hline 19 Juni 2017 & $\begin{array}{l}\text { Surat Edaran No.664/DJPT/PI/VI/2017 tentang Perpanjangan Peralihan API } \\
\text { Pukat Hela dan Pukat Tarik di WPPNRI } \rightarrow \text { s/d } 31 \text { Desember } 2017 \text { (kapal, } \leq 10 \\
\text { GT)2 }\end{array}$ \\
\hline Tanggal & Peraturan \\
\hline 11 Januari 2010 & $\begin{array}{l}\text { KEPMEN No.KEP.06/MEN/2010 tentang Alat Penangkapan Ikan di Wilayah } \\
\text { Pengelolaan Perikanan Negara Republik Indonesia }\end{array}$ \\
\hline
\end{tabular}

Direktur Kapal Perikanan dan Alat Penangkapan Ikan telah mengatur kriteria alat penangkapan ikan yang ramah lingkungan antara lain: memiliki selektivitas tinggi, hasil tangkapan sampingan (By-Catch) rendah, hasil tangkapan berkualitas tinggi, tidak merusak habitat/lingkungan (destruktif), mempertahankan keanekaragaman hayati, tidak menangkap spesies yang dilindungi/terancam punah, pengoperasian api tidak membahayakan keselamatan, tidak melakukan penangkapan di daerah terlarang, dan diterima secara sosial.

Upaya pemerintah dalam menanggulangi Illegal Fishing di Kabupaten Barru dapat dilihat dari langkah yang dilakukan oleh Dinas Perikanan Kabupaten Barru. Dalam kurun waktu 2017-2019, sebanyak 58 kali telah dilakukan sosialisasi tentang illegal fishing. Sosialisasi 
ini memberikan pemahaman kepada nelayan di Kabupaten Barru tentang alat tangkap yang dilarang dan diperbolehkan. Tidak hanya itu, nelayan juga diberi pemahaman tentang alasan larangan penggunaan alat tangkap yang illegal seperti trawl, bom ikan, dan sejenisnya.

Masih berpegangnya nelayan Siddo pada nilai-nilai kearifan lokal dalam melakukan penangkapan ikan memudahkan dinas perikanan kabupaten Barru dalam melakukan pengawasan terkait illegal fishing. Jika ada yang melakukan kegiatan illegal fishing biasanya bukan berasal dari nelayan Kabupaten Barru tetapi dari luar wilayah Barru yang masuk dan menangkap ikan di wilayah perairan Kabupaten Barru.

\section{Kesimpulan}

Intensitas kegiatan Illegal Fishing yang terjadi Kabupaten Barru tergolong rendah karena sepanjang tahun 2018 hanya ada satu kasus perikanan yang ditangani oleh Pengadilan Negeri Barru. Nilai kearifan lokal yang masih dipegang erat oleh Nelayan Desa Siddo Kabupaten Barru memberikan dampak positif, yaitu minimnya kegiatan illegal fishing. Masyarakat nelayan Desa Siddo memiliki kesadaran bahwa melakukan aktivitas penangkapan ikan dengan cara ilegal hanya akan merusak ekosistem laut. Pemerintah dalam hal ini Dinas Perikanan Kabupaten Barru telah melakukan upaya dalam menanggulangi Illegal Fishing dengan melakukan sosialisasi tentang penggunaan alat tangkap yang dilarang dan melakukan pendampingan kepada nelayan.

Bagi masyarakat, agar kiranya turut serta mengambil andil dalam menumbuhkan kesadaran tentang pentingnya menjaga ekosistem laut dengan tidak melakukan Illegal Fishing Dibentuk sebuah lembaga masyarakat untuk melestarikan dan menjaga tradisi pagae serta upacara macera tasi' agar kearifan lokal dapat dipertahankan secara turuntemurun. Bagi pemerintah, agar kiranya dapat terus melakukan upaya preventif berupa sosialisasi tentang Illegal Fishing dan melakukan penindakan tegas terhadap oknum yang melakukan aktivitas Illegal Fishing.

\section{Daftar Pustaka}

Adrianto, Luky. Konstruksi Pengelolaan Sumberdaya Perikanan di Indonesia. Bogor: IPB Press, 2011.

Ayodhyoa, A.U. Metode Penangkapan Ikan. Bogor: Yayasan Dewi Sri, 1981.

Barani, Husni Mangga. "Pemikiran Percepatan Pembangunan Perikanan Tangkap Melalui Gerakan Nasional." Last modified 2004. Diakses Oktober 15, 2019. http://www.rudyct.com/PPS702-ipb/07134/husni_mb.pdf.

Cahyadi, Robi. "Perancangan Alat Bantu Penangkap Ikan (Fishing Deck Machinery) untuk Peningkatan Produktifitas Nelayan." Prosiding Semnastek (2017).

Irianto, Sulistyowati, dan Sidharta. Metode Penelitian Hukum: Konstelasi dan Refleksi. Jakarta: Yayasan Obor Indonesia, 2011.

Lasabuda, Ridwan. "Pembangunan Wilayah Pesisir dan Lautan dalam Perspektif Negara 
Kepulauan Republik Indonesia." Jurnal Ilmiah Platax 1, no. 2 (2013): 92-101.

Masrun, Martha, Nurdin Jusuf, dan Otniel Pontoh. "Kontribusi Usaha Pukat Cincin (Purse Seine) terhadap Penyerapan Tenaga Kerja di Kelurahan Tumumpa Dua Kecamatan Tuminting Kota Manado Provinsi Sulawesi Utara." AKULTURASI: Jurnal Ilmiah Agrobisnis Perikanan 5, no. 9 (2017).

Neka, Arifin. "Analisis Kebijakan Penanggulangan Illegal Fishing di Kabupaten Halmahera Utara.” Sekolah Pascasarjana Institut Pertanian Bogor, 2010.

Sugiyono. Metode Penelitian Kuantitatif Kualitatif dan R\&D. Bandung: CV. Alfabeta, 2010.

"Menteri Susi: Kerugian Akibat Illegal Fishing Rp 240 Triliun." Detikcom. Diakses Oktober 10, 2019. https://finance.detik.com/berita-ekonomi-bisnis/d-2764211/menterisusi-kerugian-akibat-illegal-fishing-rp-240-triliun. 